\title{
MUTU LAYANAN PROGRAM JAMINAN KESEHATAN NASIONAL DI RUMAH SAKIT JIWA PEMERINTAH PROVINSI BALI
}

\author{
Ni Luh Gde Ari Natalia Yudha \\ Program Studi Kesehatan Masyarakat, Universitas Dhyana Pura \\ Email : nengnatalia@gmail.com
}

\begin{abstract}
ABSTRAK
Penyakit gangguan jiwa menimbulkan beban bagi pemerintah, keluarga serta masyarakat oleh karena produktivitas pasien menurun dan akhirnya menimbulkan beban biaya yang besar bagi pasien dan keluarga. Dari sudut pandang pemerintah, gangguan ini menghabiskan biaya pelayanan kesehatan yang besar. Rumah Sakit Jiwa Pemerintah Provinsi Bali merupakan satu-satunya rumah sakit yang melayani pasien dengan gangguan jiwa di Provinsi Bali. Tujuan penelitian ini ialah untuk mengetahui pelaksanaan program Jaminan Kesehatan Nasional (JKN) di Rumah Sakit Jiwa Provinsi Bali. Penelitian ini merupakan penelitian kualitatif dengan metode pengambilan data menggunakan wawancara mendalam. Subjek penelitian ialah petugas rumah sakit yaitu wakil direktur pelayanan medis, kabag keuangan, pemegang program JKN, petugas rekam medis, dokter dan perawat.Pasien JKN yang berobat ke rumah sakit mengalami penurunan sebesar 5,7\% atau 533 pasien rawat inap tahun 2016. Penurunan ini disebabkan peralihan Jaminan Kesehatana Bali Mandara (JKBM) ke JKN KIS. Selama pelaksanaan program JKN permasalahan yang sering terjadi yaitu pengetahuan pasien mengenai alur rujukan ke rumah sakit, jaringan internet yang kurang memadai dan ketidaklengkapan berkas sehingga memperlambat proses klaim. Perlunya sosialisasi program JKN ke masyarakat luas baik berupa media cetak maupun elektronik sehingga masyarakat bisa menggunakan pelayanan kesehatan lebih baik.
\end{abstract}

Kata kunci: rumah sakit jiwa, JKN

\section{ABSTRACT}

Psychiatric disorders pose a burden to the government, family and society because the patient's productivity decreases and ultimately creates a large burden on patients and families. From the government's point of view, this disruption costs a large amount of health services. Bali Provincial Mental Hospital is the only hospital that serves patients with mental disorders in Bali Province. The purpose of this study was to find out the implementation of the National Health Insurance (JKN) program at the Bali Provincial Mental Hospital. This research is a qualitative research with data collection methods using in-depth interviews. The subjects of the study were hospital officers, namely the deputy director of medical services, finance heads, JKN program holders, medical record officers, doctors and nurses. JKN patients who went to hospital decreased by $5.7 \%$ or 533 inpatients in 2016. Decreased this is due to the transfer of the Bali Mandara Health Insurance (JKBM) to JKN KIS. During the JKN program the most common problems were patient knowledge about the flow of referrals to the hospital, inadequate internet network and incomplete files which slowed down the claim process. The need to socialize the JKN program to the wider community in the form of print and electronic media so that people can use health services better.

Keywords: mental hospital, JKN

\section{PENDAHULUAN}

Program jaminan kesehatan nasional disingkat JKN adalah program pemerintah untuk memberikan kepastian jaminan kesehatan bagi setiap masyarakat Indonesia. Sesuai denngan Undang-Undang SJSN masyarakat dapat hidup sehat, produktif, dan sejahtera. Program ini merupakan bagian dari sistem jaminan sosial nasional (SJSN) yang bersifat wajib bagi seluruh penduduk melalui badan penyelenggara jaminan sosial (BPJS) kesehatan.

Jumlah peserta BPJS secara nasional yang terdata pada 6 november 2015 adalah sebanyak 154.111.333 jiwa. Temuan penelitian DJSN (2012) pada tahun 2014 sasaran yang dicapai dalam pengembangan JKN adalah kepuasan pasien, dimana dalam peta jalan JKN disebutkan bahwa paling sedikit $75 \%$ pasien menyatakan puas 
diberikan pelayanan oleh faskes yang bekerjasama dengan BPJS, dan akan meningkat pada tahun 2019 mencapai kepuasan pasien sebesar 85\% (Widiastuti, 2015).

Namun masih ada permasalahan yang dihadapi dalam pelaksanaan program Jaminan Kesehatan Nasional (JKN) yang terkait dengan pelayanan. Berdasarkan jajak pendapat Pusat Data Bali Post tahun 2012, mengungkapkan bahwa fenomena kurang optimalnya pelayanan kesehatan terjadi pada Pusat Kesehatan Masyarakat (Puskesmas) dan Rumah Sakit Umum Daerah (RSUD) milik pemerintah daerah. Tanggapan responden tentang kurang optimalnya pelayanan kesehatan dengan $61 \%$ responden menyatakan setuju, 35\% responden menyatakan tidak setuju dan sisanya sebanyak $4 \%$ responden menyatakan tidak tahu (Bali Post 12 Nopember 2012 dalam Suarjana, 2015). Data jajak pendapat tersebut juga menunjukkan bahwa pelayanan kesehatan untuk masyarakat Bali belum sesuai dengan harapan.

Mutu pelayanan hanya dapat diketahui apabila sebelumnya telah dilakukan penilaian, baik terhadap tingkat kesempurnaan, sifat, totalitas dari wujud serta ciri maupun kepatuhan terhadap standar yang telah ditetapkan (Herlambang, 2016). Menurut Azwar, seperti yang dipaparkan oleh Firdaus (2015) pelayanan kesehatan yang bermutu sering dikaitkan dengan pelayanan kesehatan yang baik dan memuaskan pasien. Kepuasan pasien merupakan bagian menyeluruh dalam pelaksanaan jaminan mutu layanan kesehatan, sejalan dengan pemikiran Pohan dan Koentjoro seperti yang dipaparkan oleh Widiastuti (2015) bahwa kepuasan pasien ialah dimensi mutu layanan kesehatan yang utama.

Permasalahan kesehatan tidak hanya dari kesakitan tubuh seperi demam berdarah, hepatitis atau diabetes yang bisa disembuhkan dengan tindakan medis. Permasalahan kesehatan yang dimaksud ialah gangguan mental atau jiwa yang dialami oleh masyarakat di Indonesia yang disebabkan oleh tingkat stres yang tinggi.

Prevalensi psikosis tertinggi di DI Yogyakarta dan Aceh masing-masing 2,7\%o sedangkan terendah di Kalimantan Barat 0,7\%o (Alif, 2015). Gangguan jiwa berat menimbulkan beban bagi pemerintah, keluarga serta masyarakat oleh karena produktivitas pasien menurun dan akhirnya menimbulkan beban biaya yang besar bagi pasien dan keluarga. Dari sudut pandang pemerintah, gangguan ini menghabiskan biaya pelayanan kesehatan yang besar.

Rumah Sakit Jiwa (RSJ) Pemerintah Provinsi Bali merupakan satu-satunya rumah sakit yang melayani pasien dengan gangguan jiwa di Provinsi Bali. Rumah sakit ini beralamat di Jalan Kusuma Yudha No. 29 Bangli. Memiliki 10 tempat tidur kelas VIP, 12 tempat tidur kelas I, 56 tempat tidur kelas II dan 322 tempat tidur kelas III. Rumah Sakit Jiwa Pemerintah Provinsi Bali memiliki 6 orang dokter spesialis jiwa, 1 orang dokter spesialis saraf dan 23 orang dokter umum. Jumlah pasien rawat inap penderita skizofrenia mengalami penurunan tahun 2015 sebanyak 4928 pasien menjadi 4395 pasien pada tahun 2016 sehingga terjadi penurunan sebesar 533 pasien atau $5,7 \%$. Tujuan penelitian ini adalah untuk memberikan gambaran pelayanan kesehatan di RSJ Provinsi Bali dan mengevaluasi pelaksanaan JKN pada pasien skizoprenia di RSJ Provinsi Bali.

\section{METODE}

Penelitian ini merupakan penelitian kualitatif. Penelitian kualitatif dapat didefinisikan sebagai metode penelitian yang berlandaskan pada filsafat postpositivisme, digunakan untuk meneliti pada kondisi obyek yang alamiah, dimana peneliti sebagai instrumen kunci, teknik pengumpulan data dilakukan secara triangulasi, analisis data bersifat induktif, dan hasil penelitian lebih menekankan makna daripada generalisasi (Sugiyono, 2012). Pengambilan sampel penelitian menggunakan purposive sampling untuk menentukan informan kunci. Narasumber dalam penelitian ini adalah keluarga pasien, Kepala Bagian Pelayanan Medik, Kepala Bagian Keuangan, Petugas Rekam Medis, Dokter, Perawat, Petugas Bagian JKN. Metode pengumpulan data wawancara mendalam dan observasi.

\section{HASIL DAN PEMBAHASAN}

Hasil wawancara responden keluaraga pasien Prosedur pelayanan bagian pendaftaran

Tabel 1. Kepuasan prosedur pelayanan bagian pendaftaran

\begin{tabular}{cccc}
\hline Responden $(\mathrm{R})$ & Kepuasan & Kelebihan & Hambatan \\
\hline R1 & Cukup puas & Cepat & Tidak ada \\
R2 & Puas & Prosedur cepat & Tidak ada \\
R3 & Puas & Pelayanan ramah & Tidak ada \\
\hline Kesimpulan & Puas & Pelayanan cepat dan & Tidak ada \\
& Cukup Puas & ramah & \\
\hline
\end{tabular}




\section{Pelayanan perawat}

Tabel 2. Kepuasan pelayanan perawat

\begin{tabular}{|c|c|c|c|}
\hline Responden (R) & Kepuasan & Kelebihan & Hambatan \\
\hline R1 & Puas & Sigap & Tidak ada \\
\hline R2 & Puas & $\begin{array}{l}\text { Sigap, kalau ada } \\
\text { pasien } \\
\text { langsung diikat }\end{array}$ & Tidak ada \\
\hline R3 & Puas & $\begin{array}{l}\text { Petugas cepat } \\
\text { mengambil tindakan } \\
\text { kalau ada ada gelisah } \\
\text { langsung dipndahkan } \\
\text { ke ruangan khusus }\end{array}$ & Tidak ada \\
\hline Kesimpulan & $\begin{array}{c}\text { Puas } \\
\text { Cukup Puas }\end{array}$ & $\begin{array}{l}\text { Pelayanan cepat dan } \\
\text { ramah }\end{array}$ & Tidak ada \\
\hline
\end{tabular}

\section{Pelayanan dokter}

Tabel 3. Kepuasan pelayanan dokter

\begin{tabular}{clll}
\hline Responden $(\mathrm{R})$ & \multicolumn{1}{c}{ Kepuasan } & Kelebihan & \multicolumn{1}{c}{ Hambatan } \\
\hline R1 & $\begin{array}{l}\text { Puas, karena tidak } \\
\text { bisa menangani } \\
\text { sendiri }\end{array}$ & profesional & $\begin{array}{l}\text { Jarang ketemu dokter } \\
\text { saat berkunjung }\end{array}$ \\
R2 & $\begin{array}{l}\text { Puas, demi } \\
\text { kesembuhan }\end{array}$ & profesional & $\begin{array}{l}\text { Kalau ketemu } \\
\text { dokternya jarang }\end{array}$ \\
R3 & $\begin{array}{l}\text { Biasa saja karena } \\
\text { keluarga masih } \\
\text { sakit }\end{array}$ & profesional & $\begin{array}{l}\text { Tergantung } \\
\text { pembawaannya } \\
\text { kadang-kadang } \\
\text { kurang ramah }\end{array}$ \\
& Puas & profesional & $\begin{array}{l}\text { Jarang ketemu } \\
\text { Kadang ada yang } \\
\text { kurang ramah }\end{array}$ \\
\hline Kesimpulan & & & \\
& & & \\
\hline
\end{tabular}

\section{Kondisi lingkungan fisik ruang perawatan}

Tabel 4. Kepuasan kondisi lingkungan fisik ruang perawatan

\begin{tabular}{cclc}
\hline Responden $(\mathrm{R})$ & Kepuasan & \multicolumn{1}{c}{ Kelebihan } & Hambatan \\
\hline R1 & Puas & Bersih dan nyaman & Tidak ada \\
R2 & Puas & Lingkungan sejuk & Tidak ada \\
R3 & Puas & Ruangan nyaman & Tidak ada \\
\hline Kesimpulan & Puas & $\begin{array}{l}\text { Bersih, nyaman dan } \\
\text { sejuk }\end{array}$ & Tidak ada \\
& & & \\
\hline
\end{tabular}

\section{Hasil wawancara responden dokter dan perawat} Prosedur perawatan pasien JKN

Tabel 5. Respon dokter dan perawat terhadap prosedur perawatan pasien

\begin{tabular}{|c|c|}
\hline Responden (R) & Prosedur perawatan pasien \\
\hline Dokter & $\begin{array}{l}\text { Pasien dulu memakai JKBM sekarang } \\
\text { pindah memakai JKN, pelayanan yang } \\
\text { diberikan sama dan ada beberapa obat yang } \\
\text { tidak ditanggung }\end{array}$ \\
\hline Perawat & $\begin{array}{l}\text { Tidak ada perbedaan secara prinsip } \\
\text { tindakan perawatan sama }\end{array}$ \\
\hline
\end{tabular}




\section{Kondisi ruaangan dan fasilitas}

Tabel 6. Respon dokter dan perawat terhadap kondisi ruaangan dan fasilitas

\begin{tabular}{cl}
\hline Responden $(\mathrm{R})$ & \multicolumn{1}{c}{ Kondisi ruaangan dan fasilitas } \\
\hline Dokter & Ruangan cukup bersih, alat memadai \\
Perawat & $\begin{array}{l}\text { Ruangan bersih, ada ruang tamu untuk } \\
\text { keluarga pasien, peralatan cukup }\end{array}$ \\
\hline
\end{tabular}

\section{Pemberian informasi kepada keluarga pasien}

Tabel 7. Respon dokter dan perawat terhadap Pemberian informasi kepada keluarga pasien

\begin{tabular}{cl}
\hline Responden $(\mathrm{R})$ & \multicolumn{1}{c}{$\begin{array}{c}\text { Pemberian informasi kepada keluarga } \\
\text { pasien }\end{array}$} \\
\hline Dokter & $\begin{array}{l}\text { Sudah diberikan penjelasan kepada pasien } \\
\text { baik pasien baru atau lama }\end{array}$ \\
Perawat & $\begin{array}{l}\text { Keluarga pasien diberikan edukasi sebelum } \\
\text { pasien pulang seperti pemberian obat dan } \\
\\
\end{array}$ \\
& mengenali gejala-gejala \\
\hline
\end{tabular}

Pemberian pelayanan perawatan kepada pasien JKN

Tabel 8. Respon dokter dan perawat terhadap pemberian pelayanan perawatan kepada pasien

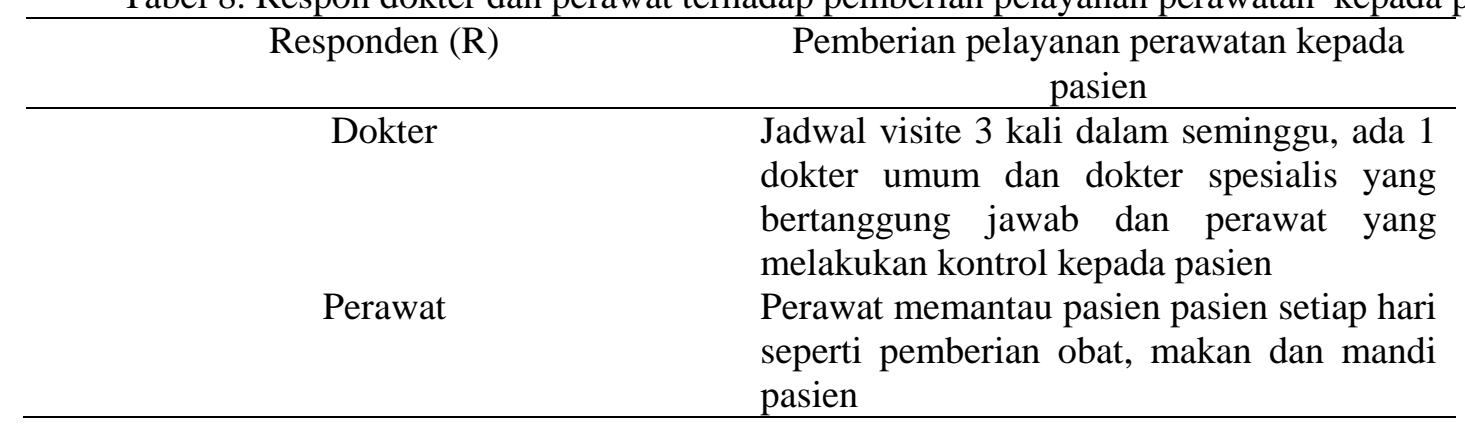

Respon petugas medis saat perawatan pasien (penangan saat pasien gelisah)

Tabel 9. Respon dokter dan perawat terhadap penangan saat pasien gelisah

\begin{tabular}{cl}
\hline Responden (R) & $\begin{array}{l}\text { Respon petugas medis saat perawatan } \\
\text { pasien (penangan saat pasien gelisah) }\end{array}$ \\
\hline Dokter & $\begin{array}{l}\text { Diisolasi di ruangan khusus kalau dokter } \\
\text { diruangan tidak ada maka memanggil } \\
\text { dokter IGD }\end{array}$ \\
Perawat & $\begin{array}{l}\text { Diisolasi, meminta bantuan satpam dan } \\
\text { memanggil dokter jaga untuk diberikan } \\
\text { suntikan }\end{array}$ \\
\hline
\end{tabular}

\section{Hasil wawancara responden pemegang program JKN}

Tabel 10. Hasil wawancara responden pemegang program JKN

\begin{tabular}{ll}
\hline \multicolumn{1}{c}{ Pertanyaan } & \multicolumn{2}{c}{ Respon pemegang program JKN } \\
\hline Prosedur pelayanan dan kelengkapan data & Pasien tidak membawa rujukan atau \\
administrasi pasien & menjadi pasien umum, pasien diarahkan ke \\
& UGD. Keluarga pasien hanya ingin \\
& mengambil obat saja tanpa pemeriksaan \\
& Eligibilitas pasien, setiap tindakan \\
& dikirimkan biayanya ke kasir menyertakan \\
& bukti kelengkapan seperti resume, tindakan \\
& lab yang kemudian dimasukkan pada \\
& software ina cbgs 5.1 \\
Ketersediaan fasilitas dan penunjang & Fasilitas di rumah sakit mencukupi, ada \\
& program droping yaitu mengantarkan \\
& pasien pulang yang didanai oleh rumah \\
\hline
\end{tabular}




\section{sakit}

Pemberian informasi yang diberikan kepada Upaya sosialisasi alur JKN dilakukan oleh keluarga pasien pihak BPJS yang berkejasama dengan perangkat desa

Hambatan saat bekerja

Tidak membawa surat rujukan, koneksi internet yang kurang lancar pengembalian berkas dari BPJS dan ketidaklengkapan berkas

Dari hasil penelitian didapatkan bahwa kepuasan pasien program JKN di RSJ Provinsi Bali mencakup banyak hal mulai dari pendaftaran sampai mendapatkan pelayanan di rawat inap. Banyak hal yang mempengaruhi kepuasan pasien antara lain: pendaftaran pasien, pelayanan cepat dan ramah, perawat dan dokter profesional, lingkungan bersih, nyaman dan sejuk. Sebaliknya hal-hal yang mempengaruhi ketidakpuasan pasien antara lain: keluarga pasien jarang ketemu dokter, dokter kurang ramah, keluarga pasien tidak tahu prosedur pelayanan pada program JKN.

Teori kepuasan SERVQUAL, dimana kepuasan pasien meliputi: reliability atau kehandalan, assurance atau jaminan, tangible atau wujud nyata, empathy atau perhatian, dan responsiveness atau kepedulian. Pada penelitian ini keluarga pasien sudah merasa puas dengan pelayanan yang diberikan dalam hal reliability atau kehandalan. Hal ini bisa dilihat dari tabel 2 dan 3, keluarga pasien merasa puas terhadap pelayanan dokter maupun perawat dimana telah memberikan pelayanan yang baik dan ramah bahkan keluarga pasien menitipkan uang kepada perawat jikalau ada keluarga mereka yang membutuhkan sesuatu. Namun, keluarga pasien masih merasa membutuhkan waktu untuk konsultasi dengan dokter karena keluarga pasien jarang bertemu dengan dokter. Hal ini menjadi kekurangan pelayanan yang dirasakan oleh keluarga pasien.

Dalam hal assurance atau jaminan pada penelitian ini, keluarga pasien merasa aman menitipkan keluarganya di rumah sakit hal ini dibuktikan keluarga pasien memiliki kedekatan dengan perawat di ruangan yang merawat keluarganya. Keluarga pasien menitipkan uang kepada perawat untuk memenuhi kebutuhan keluarganya di dalam rumah sakit serta keluarga sering menghubungi perawat lewat telepon selular. Keluarga pasien sudah mengakui kompetensi yang dimiliki dokter secara pengetahuan hanya saja keluarga pasien merasa dokter kurang ramah.

Keluarga pasien merasa puas dengan fasilitas yang tersedia di ruangan perawatan yang dilihat pada tabel 4 , keluarga pasien menyatakan ruangan perawatan bersih, nyaman dan sejuk. Namun dari hasil wawancara hal ini tidak dapat dibuktikan karena keluarga pasien hanya melihat dari luar saja.
Kepuasan dengan kondisi lingkungan fisik dan ruang perawatan termasuk dalam aspek tangible atau wujud nyata.

Sebagian besar responden menyatakan bahwa aspek kepuasan pasien empathy atau perhatian baik petugas medis maupun administrasi di rumah sakit ramah dan sopan. Namun untuk komunikasi dan perhatian yang diberikan oleh dokter masih belum sepenuhnya keluarga pasien merasa puas. Dalam hal responsiveness atau kepedulian dalam penelitian ini keluarga pasien merasa puas dilihat dari kepedulian perawat dengan pasien.

Hasil penelitian Widiastuti (2015) berdasarkan lima dimensi mutu, kepuasan responden tertinggi pada dimensi empathy (96,6\%) sedangkan kepuasan terendah pada dimensi tangibles $(71,1 \%)$. Hal ini sejalan dengan hasil penelitian Yuniarti (2015) yang menyimpulkan bahwa variabel yang paling berpengaruh adalah variabel tangibles dan emphaty sedangkan Menurut Ramez, seperti yang dipaparkan oleh Yuniarti (2015) dimensi assurance dan emphaty adalah dimensi yang paling penting dalam lingkungan perawatan kesehatan.

Dalam penelitian ini peneliti juga mencari tahu tentang perbedaan yang dirasakan sebelum dan sesudah program JKN. Ditemukan bahwa pasien yang dulunya menggunakan JKBM harus pindah memakai JKN sehingga pasien yang belum mengurus sementara dimasukkan ke pasien umum. Pasien yang menggunakan JKN masih ada yang tidak membawa rujukan puskesmas atau dokter sehingga masih menyulitkan pasien yang menyebabkan pasien menjadi pasien umum.

Dari segi kualitas pelayanan tentu saja rumah sakit rumah sakit sudah berusaha memberikan yang terbaik, baik dalam pelayanan medis dan pelayanan administrasi. Hal ini bisa dilihat dari hasil penelitian, dimana sebagai pemberi pelayanan medis yaitu dokter dan perawat dan pemberi pelayanan administrasi yaitu pemegang program JKN sudah memberikan pelayanan terbaik yang bisa mereka berikan. Meskipun masih ada beberapa kekurangan dalam hal alat atau sarana, sistem yang ada dan SDM yang masih kurang. Namun banyak hal yang dirasakan cukup baik oleh petugas medis dalam hal penanganan pasien skizoprenia yang sesuai standar. Dari sisi pemegang program JKN sudah merasa memberikan pelayanan semaksimal 
mungkin. Meskipun masih ada hambatan yang terjadi seperti pasien tidak membawa rujukan, koneksi internet yang kurang lancar pengembalian berkas dari BPJS dan ketidaklengkapan berkas. Namun secara keseluruhan kualitas pelayanan yang diberikan oleh rumah sakit sudah hampir sesuai seperti pada penelitian Lee (2000) dimana ada tujuh dimensi kualitas dalam pelayanan kesehatan yaitu jaminan (assurance), empati (empathy), kehandalan (reliability), daya tanggap (responsiveness), tampilan fisik (tangible), pelayanan medis (core medical service) dan profesionalisme (professionalism).

\section{SIMPULAN}

Kepuasan pasien skizoprenia peserta JKN terhadap kualitas pelayanan Rumah Sakit Jiwa Pemerintah Provinsi Bali secara umum sesuai dengan teori SERVQUAL, dimana kepuasan pasien meliputi: reliability atau kehandalan, assurance atau jaminan, tangible atau wujud nyata, empathy atau perhatian, dan responsiveness atau kepedulian.

Hambatan pada pelayanan di Rumah Sakit Jiwa Pemerintah Provinsi Bali yaitu ruangan dan fasilitas, kurangnya jumlah SDM, dan tata cara sistem rujukan yang belum terlaksana dengan sempurna. Solusi yang dapat diberikan yaitu menyediakan ruangan dan fasilitas internet yang memadai, standar pengisian dan kelengkapan berkas klaim, pelatihan e-klaim, membantu mensosialisasikan program JKN kepada pasien.

\section{DAFTAR PUSTAKA}

Alif Khariza, H., 2015. Program Jaminan Kesehatan Nasional: Studi Deskriptif Tentang Faktor-Faktor Yang Dapat Mempengaruhi Keberhasilan Implementasi Program Jaminan Kesehatan nasional di Rumah Sakit Jiwa Menur Surabaya. Kebijakan dan Manajemen Publik.

[online].

http://journal.unair.ac.id/filerPDF/kmp538de1 de6ffull.pdf [diakses 10 Desember 2015]

Firdaus, F.F., 2015. Evaluasi Kualitas Pelayanan terhadap Kepuasan Pasien Rawat Jalan Peserta BPJS di RSUD Panembahan Senopati Bantul. [online]. http://thesis.umy.ac.id/datapublik/t42962.pdf [diakses 10 Desember 2015]

Hayaza, Y.T., 2013. Analisis Kepuasan Pasien Terhadap Kualitas Pelayanan Kamar Obat di Puskesmas Surabaya Utara. [online].

file://C:/Users/user/Downloads/587-1744-1PB.pdf [diakses 11 November 2015]
Herlambang, S., 2016 . Manajemen Pelayanan Kesehatan Rumah Sakit. Yogyakarta : Gosyen Publishing

Lee H, Lee Y, Yoo D, 2000, 'The determinant of perceived service quality and its relationship with satisfaction', Journal of Services Marketing, Vol. 14 Iss: 3, pp.217-23.

Rumengan, D.S.S., Umboh, J.M.L, dan Kandou, G.D., 2015. [online]. Faktor - Faktor yang Berhubungan dengan Pemanfaatan Pelayanan Kesehatan pada Peserta BPJS Kesehatan di Puskesmas Paniki Bawah Kecamatan Mapanget Kota Manado. [online]. file:///C:/Users/user/Downloads/7180-154571-PB.pdf [diakses 10 Desember 2015]

Sugiyono., 2012. Metode Penelitian Kombinasi (Mixed Methoda). Bandung : ALFABETA

Saputra, M., Marlinae, L., Rahman, F., dan Dian., 2014. Program Jaminan Kesehatan Nasional dari Aspek Sumber Daya Manusia Pelaksana Pelayanan Kesehatan. [online]. Rosadihttp://journal.unnes.ac.id/nju/index.php /kemas/article/view/3462/3565 [diakses 11 November 2015]

Suarjana, M., 2015. Pengaruh Kualitas Pelayanan Terhadap Kepuasan dalam Rangka Menciptakan Loyalitas Pasien pada Rumah Sakit Umum Daerah Sanjiwani Kabupaten Gianyar. [online]. http://p3m.pnb.ac.id/dokument/jurnal/1428977 045_2.\%20NASKAH_P\%20Agung\%20Mantr a.pdf [diakses 5 November 2015]

Widiastuti., 2015. Hubungan Jenis Fasilitas Kesehatan Tingkat Pertama, Status Kepesertaan dan Karakteristik SosioDemografi dengan Tingkat Kepuasan Pasien Jaminan Kesehatan Nasional di Kota Denpasar. [online]. http://www.pps.unud.ac.id/thesis/pdf_thesis/u nud-1488-1322934605-

tesis\%20\%20ni\%20made\%20widiastuti\%20\% 20nim\%201392161018.pdf [diakses 10 Desember 2015]

Wijono, D. 2000. Manajemen mutu pelayanan kesehatan vol.2. Surabaya: Airlangga University Press

Yuniarti, S., 2015. Hubungan Antara Kualitas Pelayanan Rumah Sakit dengan Tingkat Kepuasan Pasien BPJS di Ruang Perawatan RSUD Sultan Syarif Mohamad Alkadrie Kota Pontianak Tahun 2015. [online].

http://jurnal.untan.ac.id/index.php/jmkeper awatanFK/article/view/11039/10507

$\begin{array}{lll}\text { [diakses } & 9 & \text { November } \\ \end{array}$

